Portland State University

PDXScholar

Engineering and Technology Management

Faculty Publications and Presentations

8-2-2015

\title{
Financial Analysis and Comparison of Compact Electric and Gasoline Cars
}

Jing Jiang

Biamp Systems Inc.

Alexander Blank

Portland State University

Felix Maier

Portland State University

Anjan Bharthepudi

Portland State University

Follow this and additional works at: https://pdxscholar.library.pdx.edu/etm_fac

Part of the Operations Research, Systems Engineering and Industrial Engineering Commons Let us know how access to this document benefits you.

\section{Citation Details}

Jiang, J., Blank, A., Maier, F., Bharthepudi, A., \& Kumar, P. (2015, August). Financial analysis and comparison of compact electric and gasoline cars. In Management of Engineering and Technology (PICMET), 2015 Portland International Conference on (pp. 511-518). IEEE.

This Article is brought to you for free and open access. It has been accepted for inclusion in Engineering and Technology Management Faculty Publications and Presentations by an authorized administrator of PDXScholar. Please contact us if we can make this document more accessible: pdxscholar@pdx.edu. 


\title{
Financial Analysis and Comparison of Compact Electric and Gasoline Cars
}

\author{
Jing Jiang ${ }^{1}$, Alexander Blank ${ }^{2}$, Felix Maier ${ }^{2}$, Anjan Bharthepudi ${ }^{2}$, Pramod Kumar ${ }^{2}$ \\ ${ }^{1}$ Biamp Systems Inc., Beaverton, OR - USA \\ ${ }^{2}$ Department of Engineering and Technology Management, Portland State University, Portland, OR - USA
}

\begin{abstract}
In the paper, a PESTLE (political, economic, social, technical, legal, and environmental) analysis is used to conduct an initial evaluation for electric vehicles (EV) and gasoline cars. Furthermore, two cash flow models are created to describe the scenarios of both gasoline and electric car respectively. Based upon the proposed models, the equivalent uniform annual cost (EUAC) methodology is used to calculate the cost during the period of car ownership. Four compact EVs and five compact gasoline cars are selected in the analysis. The results expose that the actual return of federal tax credit impacts the EUAC value. The $50 \%$ return of tax credit will cause that the gasoline car is the winner during ownership. A EUAC sensitivity analysis against gasoline prices and different return of tax credit is also performed. Our work can help individuals to create some sort of economic awareness on buying EVs or gasoline cars.
\end{abstract}

\section{INTRODUCTION}

The increase in population in the next years, and the number of vehicle operations will increase globally by millions to billions. If the gasoline vehicles with internal combustion engine propel all these vehicles, one can raise the question where the required oil will come from and what the ramifications in the future could be. Naturally, there will be an increasing pollution of the environment. Although electric vehicles already have been existing for approximately 200 years[1], their real breakthrough triggered by the rising awareness of environmentalism was at the beginning of the 21 st century[2]. They play an important role in addressing issues like reducing petroleum dependency and emissions.

The demand for electric cars was increasing and oil prices kept going up over the past few years, electric cars are marketed as the next big thing and also as a solution to save money. The overwhelming amount of federal, state, and local support for the national transition to the use of electric cars, combined with strong collaborations between the car manufacturers, industries and policy makers, make everyone expect the electric cars to take over the US market. Electric car manufacturers and consumers are offered many incentives by the state and federal governments to encourage the sales of electric cars[3]. These electric cars are considered to be environmental friendly as they consume negligible to zero fossil fuels, very easy to handle, efficient and reliable. The electric cars seem to be on the verge of breaking through because they offer significant environmental benefits, especially in the urban areas. Innovative business models are designed in such a way that they would boost consumer acceptance and overcome the remaining barriers such as high battery costs, green electricity supply, and charging infrastructure.
In almost every country, and especially in the USA, it is cheaper to power up an electric vehicle than to fuel up a gasoline one[4]. An electric car will not spoil the environment highly because it releases less carbon dioxide pollution than a gasoline car with an internal combustion engine. The disadvantage of an electric car is the high initial investment to own the vehicle, but savings can be earned with respect to the gasoline prices and annual maintenance. Right now, the battery life time of electric cars is a subject to debate about[5][6], but improving technology is constantly adding to performance and efficiency.

\section{METHODOLOGY}

The decision to conduct the analysis with focus on the near future within the current topic was based on the research finding that the average car ownership in the US is about six years. Within the PESTLE (Political, Economic, Social, Technological, Legal, and Environmental) analysis, both the technologies themselves as well as their markets are dissected. This analysis serves as the fundamental base of the financial analysis.

Through literature and data research it turned out that the market for the electric cars was more dominant in the compact car segment than in any other segments. Although there are a few representatives for electric cars in other segments, such as standard and sedan class, they are still not close enough to the number available for the same segment of gasoline cars. Hence, it was decided to stick to compact car segment in each type. In the compact car segment of each type, through the data collected for all variants from different sources, nine cars in total were chosen. Four representatives from the electric cars segment, which are Honda Fit $\boldsymbol{E} \boldsymbol{V}$, Chevrolet Spark, Nissan Leaf, Ford Focus BEV. The gasoline cars chosen for the financial comparison with the electric cars are Kia Soul, Toyota Corolla L, Mazda3 I SV, Honda Civic LX, Ford Focus S Sedan.

After considering many factors for the financial comparison, the final decision was made on the following seven factors: Depreciation, Financing, Insurance, State fees, Maintenance cost, Fuel, Repairs.

At first, the EUAC value was calculated for the period of ownership up to six years for each car in each segment. Finding out the EUAC value makes it possible to recognize the best car during ownership. Also, with the help of EUAC values, one can see the difference in values for each car of each type. Combining the differences for all the six years, one can observe a trend to decide if the EUAC values are constantly increasing, decreasing or fluctuating constantly. 
In addition, a sensitivity analysis for fluctuation in both tax credit and gas/electricity price was conducted. The intention in applying a sensitivity analysis is on the one hand to find out the critical values at which the results of a scenario change from one to the other and makes it possible on the other hand to find out the most economic ownership period of a car.

\section{PESTLE ANALYSIS}

Based on the reviewing of articles and web sources, an analysis of both the electric cars and the gasoline cars with PESTLE is possible to see what external macro effects do have an influence on the technologies as well as on the respective market for the vehicles. Here it is important to mention that only the effects of the respective surrounding characteristics on the technologies were considered and not pros/cons of the electric/gasoline car within the fields of PESTLE.

\section{A. Political Impacts}

The US government provides tax incentives for the owner of electric cars that allow getting a tax credit depending on the purchasing year, the state and especially the income level of the owner[7] . Moreover is the United States' National Innovation System interested in keeping/building the nation's competitive advantage in the PEV-car technology and provides therefore through the Department of Energy Load Programs Office (LPO) annual funding for innovative technologies $[8][9][10][11]$. The gasoline cars on the other hand are politically influenced by heavy lobbying in the USA, which results in a strong market position [12]. Furthermore does the US economy rely among other things on ongoing consumption of gasoline cars to maintain growth and nationwide affluence, but the government does also require the car manufacturers to make the engines more fuel efficient, which leads to constantly new challenges.

\section{B. Economic Impacts}

PEVs are affected by long charging times, which is a loss in time and especially difficult in long journeys and can thus indirectly be considered as higher costs. Since economies of scale are not as developed as economies of scope for the manufacturing of electric cars and the used materials like the battery are more expensive, the production costs are significantly higher and as a consequence the retail price customers have to pay is obviously higher compared to gasoline cars [13][14]. The fact that the technology is not as much exploited and not as sophisticated yet as the gasoline cars, electric vehicles tend to have an increased sensitivity to scarcities, therefore increased maintenance costs and a much faster loss of value[15][16][17]. This will be considered in more detail in the "Technological" section of the PESTLE. Insurance policies for PEVs are moreover mainly the same as for gasoline cars. The reason is that insurance companies do not establish any specific models for electric vehicles and thus EVs are just handled as normal gasoline cars. Some insurance providers however, offer higher prices for PEVs, which is of course an economical liability for the owners [18][19][20] [21] . Another issue still not elaborated yet is the evacuation of old batteries after their lifetime. Who is going to pay for this? Will it be covered by insurance companies, by the car manufacturers, the government, or the car owners themselves? Whoever will be the carrier of the evacuation costs is going to be an additional financial liability [22][23]. Another very important, maybe the most important factor of cost comparison concerning the viability, is the energy and especially the gas price. The Oil price decreased alone in the last 6 months form over $\$ 100$ per barrel to $\$ 61$ per barrel and with the U.S. becoming the world's largest oil producer in 2017 this trend is very likely to continue [24][25]. Obviously, this is going to harm the ambition to push forward the dissimilation of electric vehicles.

\section{Social Impacts}

The awareness of environmental and ecological issues in the public is experiencing a significant increase over the last couple of years and people feel more responsible for their actions and their ecological impact. On the other hand safety concerns like burning batteries are still negatively influencing the consumer's decisions. Furthermore, gasoline cars are still a part of the American culture as a status symbol and proved their practicability over centuries, which resulted in a high degree of trust. Another critical point is the question, how the energy to charge the cars is produced. If this energy comes mainly from fossil sources, the entire electric car topic would turn into a classic example of greenwashing and totally fail its purpose[26] [27][28].

\section{Technological Impacts}

The technological effects on electric cars are the low mileage related to battery life, which leads to trouble due to long distances to be covered [13][26] in the northwest and especially in cold seasons [29][30]. On the other hand provides the lightweight-construction [13] of the cars technically an efficiency of $80-90 \%$. This however is only valid if the energy to charge the car is exclusively produced by renewable energies. If the power comes from fossil energy the efficiency decreases dramatically fewer than $30 \%$, which makes it actually lower than for gasoline cars [31]. Even if the threat is really low, batteries still might blow up and represent thus a danger for the owners[32] [33]. Another issue is the still long charging times for PEVs. The most powerful chargers right now still take up to 30 minutes[34]. This is especially on long journeys or for business trips a nogo. The entire production process of gasoline cars is moreover highly driven by economies of scale, which makes it really hard to compete, even though the manufactures can use the established economies of scope [35] . The industry is in contrast to the PEVs very mature with tons of innovations and technologies and continuous improving engines and production processes [12][25]. 


\section{E. Environmental Impacts}

The Environmental impacts on the electric cars are a technically infinite source of power, if the electricity is produced through renewable energies, which is not the case for the entire US [27] [28]. Gasoline cars on the other hand are dependent on a finite source of fossil oil. However, as already stated above, the oil production in the US increases massively and prices are declining. A further issue is moreover the disposal of batteries. There don't exist any reliable models on how to proceed with this highly toxic waste yet [22][23].

\section{F. Legal Impacts}

Right now there exist two main standards for fastcharging technologies for electric vehicles in the US, they cannot be used with each other. Thus a legally forced standardization is required [36]. Furthermore does the question arise, whether the government or the companies are paying for the extension of the charging infrastructure [37] and if there might be further incentives for the OEMs to produce more electric vehicles [38]. Gasoline cars in contrast underlie a progressive legal regulation of the emissions [39].

\section{FINANCIAL ANALYSIS}

There are many different models of gasoline cars, but there are not many models of EV cars. Most of affordable EV cars are of compact size. Based upon the American Best Affordable Car List[40] and Edmonds list[41], four compact EV cars and five compact gasoline cars (Table 1) are selected for comparison and analysis.

The statistic [42][43] shows the length of car ownerships in the United States. In 2012, new-car buyers kept their vehicles for about 71.6 months. The length of car ownerships depends on the overall job market. If the unemployment rate is high, the new-vehicle market will slow down and people will keep their vehicles longer. Now, it has returned to just over 66 months of ownership[44]. Based upon the average length of car ownership, the studying period of our economy analysis in the paper is up to six years.

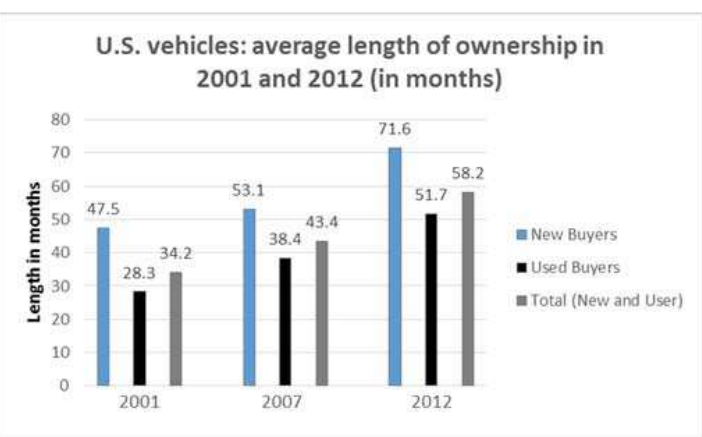

Figure 1 - Length of car ownership

In order to perform the financial analysis, one needs to determine the minimum acceptable rate of return (MARR). Based upon the U.S. Department of the treasury [45], it is possible to find out five-year and seven-year $\mathrm{T}$ note rates that are $1.63 \%$ and $2.05 \%$ respectively. The studying period can go up to six years and thus the average of the five-year and seven-year rate was taken, which means in numbers a MARR rate of $1.84 \%$.

Figure 2 and Figure 3 demonstrate the cash flow model for a gasoline car and an electric car respectively. The difference is the tax credit for an electric car. The tax credit is not a price reduction, so we cannot deduct it from the initial purchasing price. The actual return may also depend on the individual income. At this point the assumption is made that the customer will get the maximum return of tax credit which is $\$ 7,500$ [7][46]. The variation of return of the tax credit will be considered in the sensitivity analysis. Some states [46] may have other incentives for EV cars, but within this paper there is not a focus on the local incentives in order to reduce the complexity. The market value of a car will be different every year because of deprecation, and the annual expense is different as well because maintenance cost, repair cost, fuel cost, etc. may change. The car owner will not make profit during the ownership of the car, but he/she would like to minimize the cost during the ownership.

There are a few different methodologies [47], such as $\mathrm{PW}, \mathrm{FW}, \mathrm{AW}, \mathrm{CW}$, and EUAC to perform economic analysis for owning a car. EUAC is the best way to evaluate the cost for owning a car. The less EUAC will be economically good.

TABLE 1 - COMPACT CARS FOR ANALYSIS

\begin{tabular}{|c|c|c|c|c|c|c|c|c|}
\hline \multicolumn{3}{|c|}{ EV cars } & \multicolumn{3}{c|}{ Gasoline cars } \\
\hline $\begin{array}{c}\text { Honda } \\
\text { Fit EV } \\
\text { 4Dr Hatchback }\end{array}$ & $\begin{array}{c}\text { Chevrolet } \\
\text { Spark EV }\end{array}$ & $\begin{array}{c}\text { Nissan } \\
\text { LEAF S } \\
\text { 4Dr Hatchback }\end{array}$ & $\begin{array}{c}\text { Ford } \\
\text { Focus BEV } \\
\text { 4Dr Hatchback }\end{array}$ & $\begin{array}{c}\text { Kia } \\
\text { Soul } \\
\text { 4Dr Wagon }\end{array}$ & $\begin{array}{c}\text { Toyota } \\
\text { Corolla L } \\
\text { 4Dr Sedan }\end{array}$ & $\begin{array}{c}\text { Mazda } \\
\text { Mazda3 i SV } \\
\text { 4Dr Sedan }\end{array}$ & $\begin{array}{c}\text { Honda } \\
\text { Civic LX } \\
\text { 4Dr Sedan }\end{array}$ & $\begin{array}{c}\text { Ford } \\
\text { Focus S } \\
\text { 4Dr Sedan }\end{array}$ \\
\hline$\$ 36,625$ & $\$ 27,010$ & $\$ 28,980$ & $\$ 35,170$ & $\$ 16,900$ & $\$ 17,400$ & $\$ 17,995$ & $\$ 19,190$ & $\$ 16,810$ \\
\hline
\end{tabular}




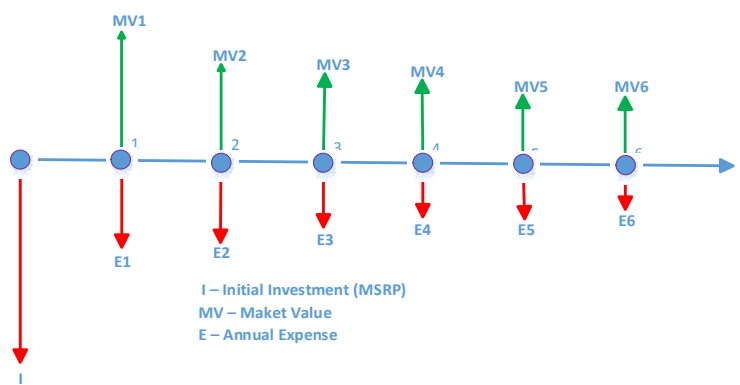

Figure 2 - Cash flow model for a gasoline car

The equation below is used to calculate the EUAC value:

$$
\begin{gathered}
E U A C_{k}(i \%)_{E V}=I\left(\frac{A}{P}, i \%, k\right)-\left(T C\left(\frac{P}{F}, i \%, 1\right)\right)\left(\frac{A}{P}, i \%, k\right)- \\
M V_{k}\left(\frac{A}{F}, i \%, k\right)+\left[\sum_{j=1}^{k} E_{j}\left(\frac{P}{F}, i \%, j\right)\right]\left(\frac{A}{P}, i \%, k\right) \\
E U A C_{k}(i \%)_{\text {Gasoline }}=I\left(\frac{A}{P}, i \%, k\right)-M V_{k}\left(\frac{A}{F}, i \%, k\right)+ \\
{\left[\sum_{j=1}^{k} E_{j}\left(\frac{P}{F}, i \%, j\right)\right]\left(\frac{A}{P}, i \%, k\right)}
\end{gathered}
$$

Where $\mathrm{I}=$ initial investment (MSRP of a car)

$\boldsymbol{M} \boldsymbol{V}_{\boldsymbol{k}}=$ market value at the end of the $\mathrm{k}_{\mathrm{th}}$ study period $\mathbf{K}=$ study period

$\mathbf{T C}=$ tax credit

We define

$$
C E_{k}(i \%)=\sum_{j=1}^{k} E_{j}\left(\frac{P}{F}, i \%, j\right)
$$

We call CE as cumulative expense.

Thus, by substituting the CE(i\%) expression of equation (3) into the express (1) and (2), equation (1) and (2) become

$$
\begin{gathered}
E U A C_{k}(i \%)_{E V}=I\left(\frac{A}{P}, i \%, k\right)-\left(T C\left(\frac{P}{F}, i \%, 1\right)\right)\left(\frac{A}{P}, i \%, k\right)- \\
M V_{k}\left(\frac{A}{F}, i \%, k\right)+C E_{k}\left(\frac{A}{P}, i \%, k\right) \\
E U A C_{k}(i \%)_{\text {Gasoline }}=I\left(\frac{A}{P}, i \%, k\right)-M V_{k}\left(\frac{A}{F}, i \%, k\right)+ \\
C E_{k}\left(\frac{A}{P}, i \%, k\right)\left(\frac{A}{P}, i \%, k\right)
\end{gathered}
$$

The data for six years was obtained from IntelliChoice' website[48][49][50][51][52][53][54][55][56], and the data is

\begin{tabular}{|c|c|c|c|c|c|c|c|c|}
\hline \multicolumn{9}{|c|}{2014 Toyota Corolla L 4Dr Sedan } \\
\hline Tax credit & 0 & & & & & & & \\
\hline PW of TC & 0 & & & & & & & \\
\hline MARR & $1.84 \%$ & \multicolumn{7}{|c|}{ Year } \\
\hline \multirow{2}{*}{\multicolumn{2}{|c|}{ MSRP }} & 0 & 1 & 2 & 3 & 4 & 5 & 6 \\
\hline & & $\$ 17,400$ & & & & & & \\
\hline \multicolumn{2}{|c|}{ Depreciation } & & $\$ 3,319$ & $\$ 1,261$ & $\$ 1,247$ & $\$ 1,100$ & $\$ 983$ & $\$ 870$ \\
\hline \multicolumn{2}{|l|}{ MV } & & $\$ 14,081$ & $\$ 12,820$ & $\$ 11,573$ & $\$ 10,473$ & $\$ 9,490$ & $\$ 8,620$ \\
\hline & Financing & & $\$ 675$ & $\$ 538$ & $\$ 395$ & $\$ 246$ & $\$ 87$ & $\$ 0$ \\
\hline & Insurance & & $\$ 1,468$ & $\$ 1,468$ & $\$ 1,468$ & $\$ 1,468$ & $\$ 1,468$ & $\$ 1,468$ \\
\hline & State Fees & & $\$ 103$ & $\$ 67$ & $\$ 68$ & $\$ 64$ & $\$ 64$ & $\$ 64$ \\
\hline & Fuel & & $\$ 1,534$ & $\$ 1,558$ & $\$ 1,583$ & $\$ 1,609$ & $\$ 1,634$ & $\$ 1,659$ \\
\hline & \begin{tabular}{|l|} 
Maintenance \\
\end{tabular} & & $\$ 0$ & $\$ 17$ & $\$ 468$ & $\$ 691$ & $\$ 487$ & $\$ 700$ \\
\hline & Repairs & & $\$ 0$ & $\$ 0$ & $\$ 74$ & $\$ 160$ & $\$ 324$ & $\$ 600$ \\
\hline cost & Overall & & $\$ 3,780$ & $\$ 3,648$ & $\$ 4,056$ & $\$ 4,238$ & $\$ 4,064$ & $\$ 4,491$ \\
\hline \begin{tabular}{|l|l}
$\mathrm{CE}$ \\
\end{tabular} & & & $\$ 3,712$ & $\$ 7,099$ & $\$ 10,940$ & $\$ 14,879$ & $\$ 18,589$ & $\$ 22,615$ \\
\hline EUAC & & & $\$ 7,418$ & $\$ 6,237$ & $\$ 6,009$ & $\$ 5,897$ & $\$ 5,771$ & $\$ 5,733$ \\
\hline
\end{tabular}
based upon the 15,000 miles each year. The 6th year is based upon the car deprecation rate [57][58] to evaluate the market value for the car. In fact, the depreciation rate is determined by a few different factors such as the economy, the price of gasoline, the number of miles one drives its car, the condition of the car, and the demand for the particular maker and model of the car.

TABLE 2 - CALCULATION GASOLINE VEHICLE

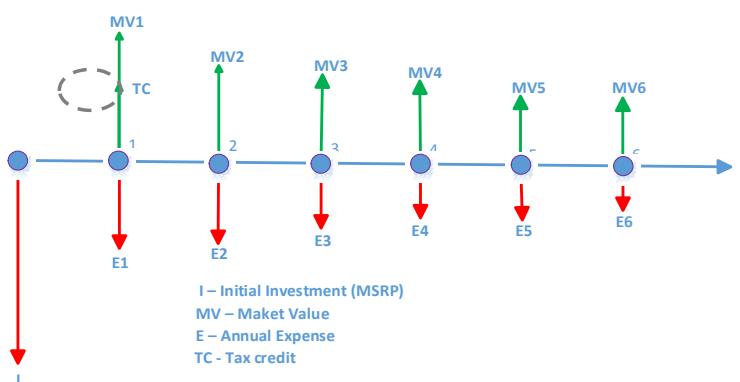

Figure 3 - Cash flow model for an EV car

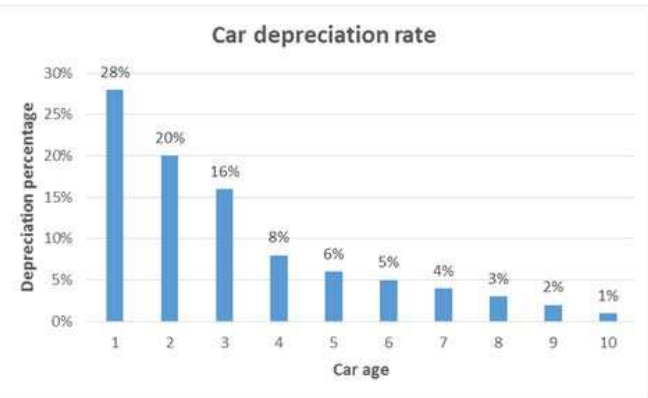

Figure 44 - Car depreciation rate

\section{RESULTS}

Table 2 and Table 3 are exemplary for the calculation of the EUAC for electric respectively gasoline cars. It is assumed that the owner gets full $\$ 7,500$ tax credit as a return. As mentioned above, the owner may not get the full amount of tax return and if not, this is going to impact the EUACs. The line of $\mathrm{CE}$ in the table is the cumulative expense defined by equation 3 . The line of PW of TC is the present worth of the return of tax credit. Generally speaking, the number of EUAC will be decreasing with the increase of the ownership period. However, the EUAC number for an EV may experience an increase and then decrease because of the tax credit.

Table 4 shows the EUAC comparison of all cars in case of the full $100 \%$ tax credit. For this case, the Chevrolet Spark EV 2LT 4Dr Hatchback is the economically most viable car.

Table 5 shows the EUAC comparison for only $50 \%$ tax credit where the Toyota Corolla L 4Dr Sedan stands out economically. 
2015 Proceedings of PICMET '15: Management of the Technology Age

TABLE 4 - EUAC COMPARISON WITH FULL TAX CREDIT BACK

\begin{tabular}{|c|c|c|c|c|c|c|c|c|}
\hline & & & \multicolumn{6}{|c|}{ EUAC } \\
\hline Fuel Type & Car model & MSRP & $\mathrm{Y1}$ & Y2 & $\overline{Y 3}$ & $\mathrm{Y4}$ & Y5 & Y6 \\
\hline \multirow{4}{*}{ Z } & Honda Fit EV 4Dr Hatchback & $\$ 36,625$ & $\$ 8,138$ & $\$ 6,996$ & $\$ 6,665$ & $\$ 6,522$ & $\$ 6,340$ & $\$ 6,173$ \\
\hline & Chevrolet Spark EV 2LT 4Dr Hatchback & $\$ 27,010$ & $\$ 5,504$ & $\$ 5,371$ & $\$ 5,409$ & $\$ 5,453$ & $\$ 5,351$ & $\$ 5,244$ \\
\hline & Nissan LEAF S 4Dr Hatchback & $\$ 28,980$ & $\$ 4,509$ & $\$ 5,413$ & $\$ 5,782$ & $\$ 5,977$ & $\$ 5,915$ & $\$ 5,739$ \\
\hline & Ford Focus BEV 4Dr Hatchback & $\$ 35,170$ & $\$ 6,320$ & $\$ 6,978$ & $\$ 7,208$ & $\$ 7,331$ & $\$ 7,163$ & $\$ 6,890$ \\
\hline \multirow{5}{*}{ 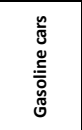 } & Kia Soul 4Dr Wagon & $\$ 16,900$ & $\$ 8,138$ & $\$ 6,996$ & $\$ 6,665$ & $\$ 6,522$ & $\$ 6,340$ & $\$ 6,173$ \\
\hline & Toyota Corolla L 4Dr Sedan & $\$ 17,400$ & $\$ 7,418$ & $\$ 6,237$ & $\$ 6,009$ & $\$ 5,897$ & $\$ 5,771$ & $\$ 5,733$ \\
\hline & Mazda Mazda3 i SV 4Dr Sedan & $\$ 17,995$ & $\$ 7,537$ & $\$ 6,478$ & $\$ 6,169$ & $\$ 6,043$ & $\$ 5,874$ & $\$ 5,747$ \\
\hline & Honda Civic LX 4Dr Sedan & $\$ 19,190$ & $\$ 8,504$ & $\$ 6,985$ & $\$ 6,541$ & $\$ 6,315$ & $\$ 6,092$ & $\$ 5,914$ \\
\hline & Ford Focus S 4Dr Sedan & $\$ 16,810$ & $\$ 8,163$ & $\$ 6,849$ & $\$ 6,507$ & $\$ 6,278$ & $\$ 6,110$ & $\$ 5,967$ \\
\hline
\end{tabular}

TABLE 5 - EUAC COMPARISON WITH HALF TAX CREDIT BACK

\begin{tabular}{|c|c|c|c|c|c|c|c|c|}
\hline \multirow[b]{2}{*}{ Fuel Type } & \multirow[b]{2}{*}{ Car model } & \multirow[b]{2}{*}{ MSRP } & \multicolumn{6}{|c|}{ EUAC } \\
\hline & & & Y1 & Y2 & Y3 & Y4 & Y5 & Y6 \\
\hline \multirow{4}{*}{ ש } & Honda Fit EV 4Dr Hatchback & $\$ 36,625$ & $\$ 9,085$ & $\$ 8,178$ & $\$ 7,728$ & $\$ 7,445$ & $\$ 7,220$ & $\$ 6,896$ \\
\hline & Chevrolet Spark EV 2LT 4Dr Hatchback & $\$ 27,010$ & $\$ 9,254$ & $\$ 7,263$ & $\$ 6,682$ & $\$ 6,416$ & $\$ 6,128$ & $\$ 5,898$ \\
\hline & Nissan LEAF S 4Dr Hatchback & $\$ 28,980$ & $\$ 8,259$ & $\$ 7,305$ & $\$ 7,055$ & $\$ 6,940$ & $\$ 6,693$ & $\$ 6,393$ \\
\hline & Ford Focus BEV 4Dr Hatchback & $\$ 35,170$ & $\$ 10,070$ & $\$ 8,870$ & $\$ 8,481$ & $\$ 8,294$ & $\$ 7,941$ & $\$ 7,544$ \\
\hline \multirow{5}{*}{ 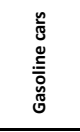 } & Kia Soul 4Dr Wagon & $\$ 16,900$ & $\$ 8,138$ & $\$ 6,996$ & $\$ 6,665$ & $\$ 6,522$ & $\$ 6,340$ & $\$ 6,173$ \\
\hline & Toyota Corolla L 4Dr Sedan & $\$ 17,400$ & $\$ 7,418$ & $\$ 6,237$ & $\$ 6,009$ & $\$ 5,897$ & $\$ 5,771$ & $\$ 5,733$ \\
\hline & Mazda Mazda3 i SV 4Dr Sedan & $\$ 17,995$ & $\$ 7,537$ & $\$ 6,478$ & $\$ 6,169$ & $\$ 6,043$ & $\$ 5,874$ & $\$ 5,747$ \\
\hline & Honda Civic LX 4Dr Sedan & $\$ 19,190$ & $\$ 8,504$ & $\$ 6,985$ & $\$ 6,541$ & $\$ 6,315$ & $\$ 6,092$ & $\$ 5,914$ \\
\hline & Ford Focus S 4Dr Sedan & $\$ 16,810$ & $\$ 8,163$ & $\$ 6,849$ & $\$ 6,507$ & $\$ 6,278$ & $\$ 6,110$ & $\$ 5,967$ \\
\hline
\end{tabular}

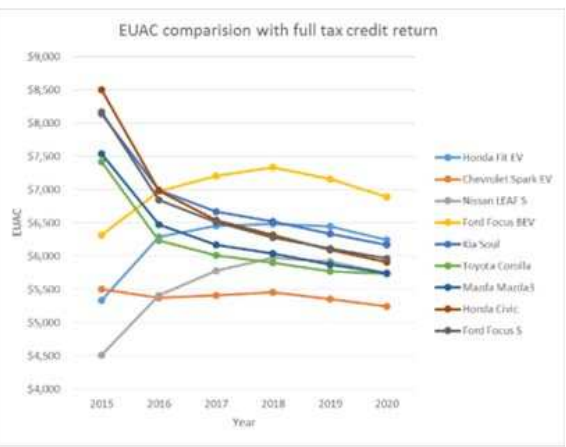

(a)

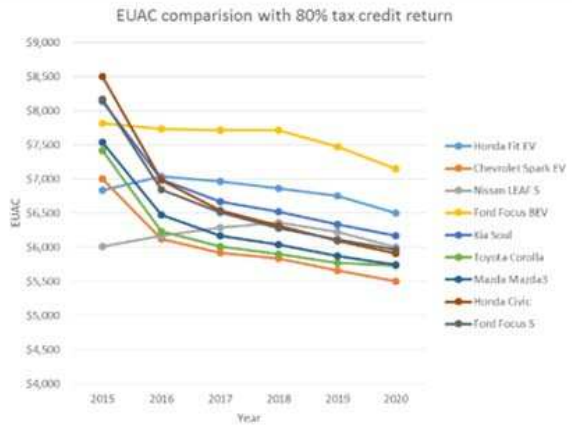

(c)

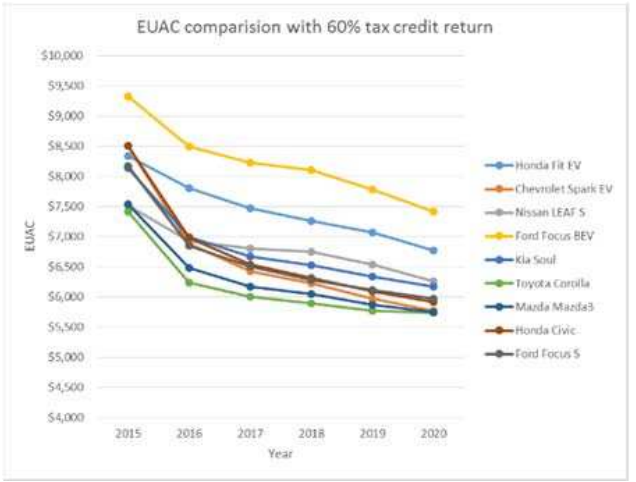

(e)

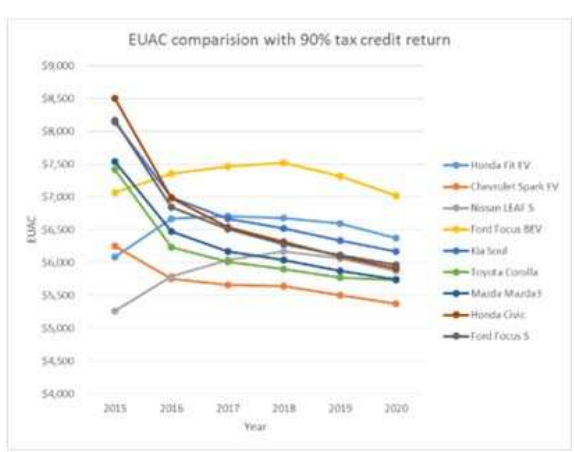

(b)

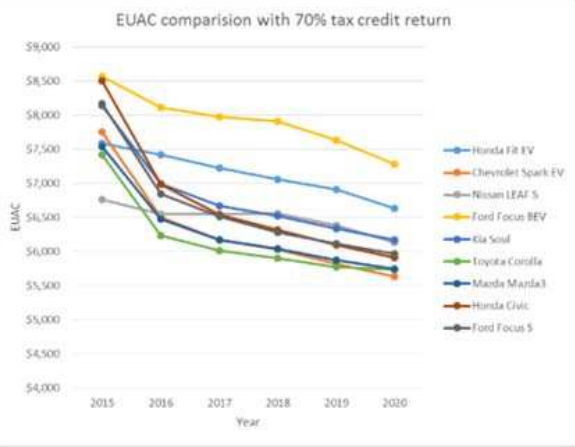

(d)

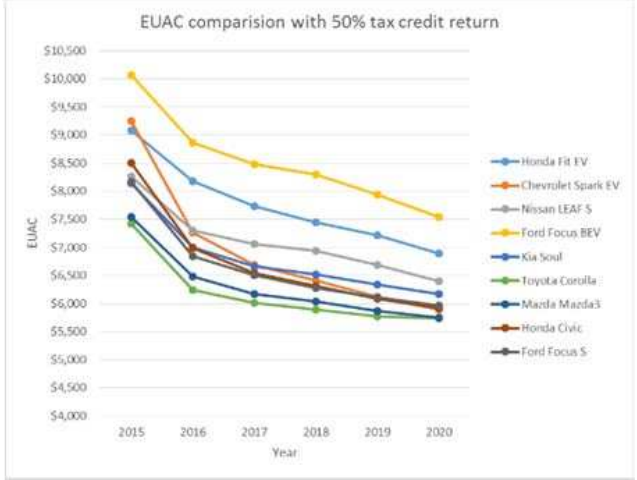

(f)

Figure 5 - Sensitivity Analysis against the Return of Tax Credit 
Figure 5 shows the sensitivity to the return of the tax credit. Chevrolet Spark EV 2LT 4Dr Hatchback is still economic until the $70 \%$ return of the tax credit. If the return is less than $70 \%$ of the tax credit, Toyota Corolla L 4Dr Sedan will be the winner.

The fuel (electric and gasoline) price is another major factor impacting the calculation. The Electricity price is relative stable whereas gasoline prices are impacted by many uncertain factors, and the change does impact the decision. Table 6 shows the national average prices for electricity and gasoline. The gasoline in 2015 could be decreased by $13.27 \%$.

Figure 6 shows the EUAC sensitivity against the change of gasoline prices:

- In Figure 5(a), the return of tax credit is $100 \%$, and the Chevrolet Spark EV is the winner. If the gasoline price is decreased simply by $14 \%$, nothing changes and the Chevrolet Spark EV is still best. If the gasoline price is decreased simply by $30 \%$ shown in Figure 6(d), the Toyota corolla will be the winner if the car is owned for four years or longer.

- In Figure 5(d), the return of tax credit is $70 \%$, and the Chevrolet Spark EV is the most economic one if the consumer owns the car for six years. If the gasoline price is decreased simply by $14 \%$, Figure $6(\mathrm{~b})$ displays that the Toyota corolla will be the winner.

- In Figure 5(f), the return of the tax credit is 50\%, and the Toyota corolla is the winner. If the gasoline price is increased simply by $14 \%$, Fig 6(a) exhibits that the Chevrolet Spark EV will be the winner if the car is owned for six years.

TABLE 6 - EIA (U.S. ENERGY INFORMATION ADMINISTRATION) PRICE FORECAST [59]

\begin{tabular}{|l|c|c|c|c|}
\cline { 2 - 5 } \multicolumn{1}{c|}{} & \multicolumn{4}{|c|}{ Year } \\
\cline { 2 - 5 } & 2012 & 2013 & 2014 & 2015 Projected \\
\hline Gasoline (\$/gallon. National Wide Average Pump Price) & 3.63 & 3.51 & 3.39 & 2.94 \\
\hline Electricity ( $\ell /$ kwh, Residential Average) & 11.88 & 12.12 & 12.48 & 12.7 \\
\hline
\end{tabular}

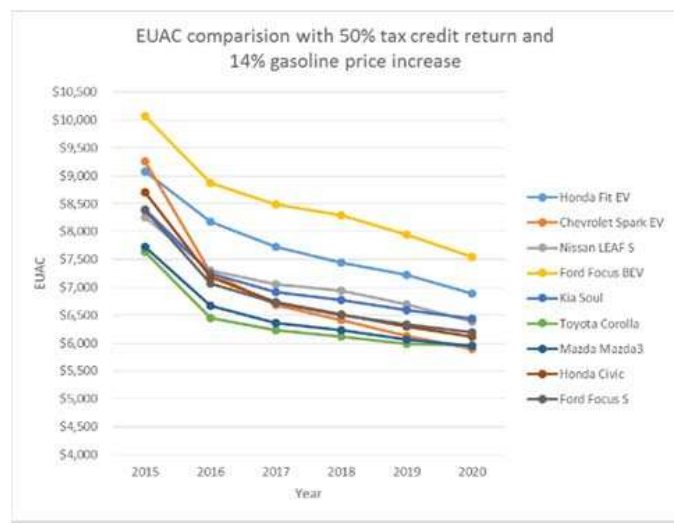

(a)

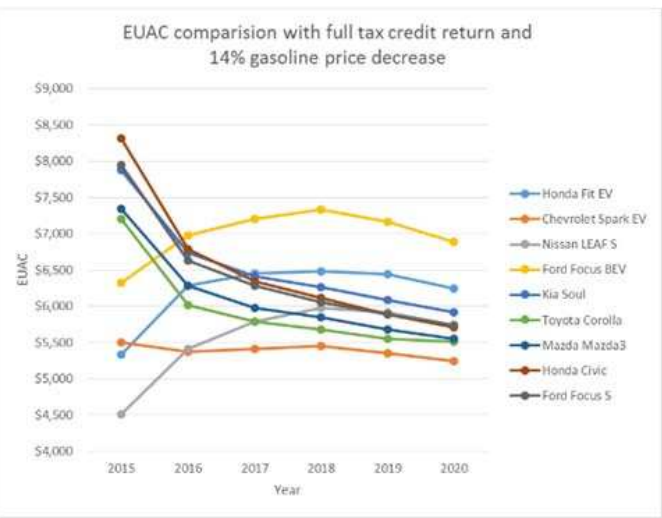

(c)

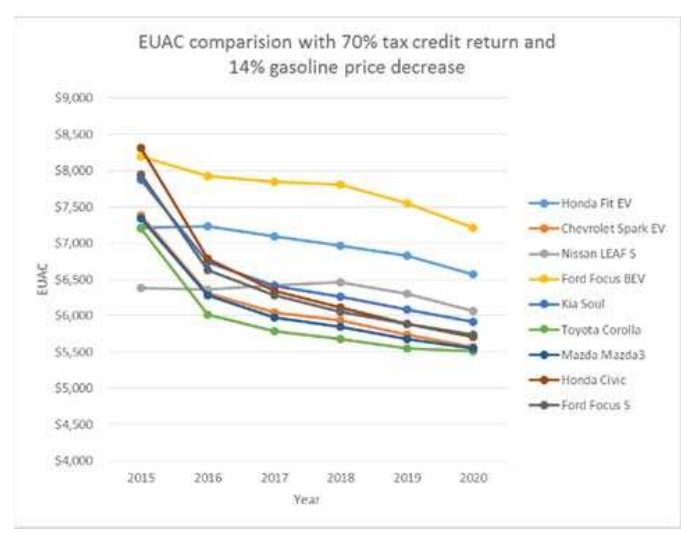

(b)

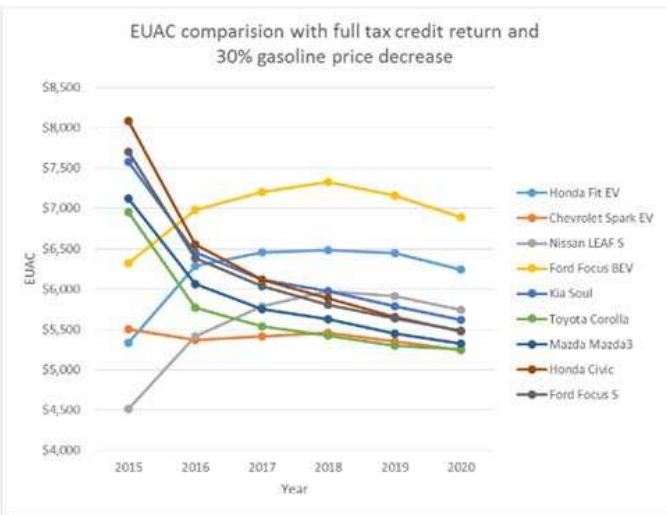

(d)

Figure 66 - Sensitivity Analysis against Gasoline Prices 


\section{Proceedings of PICMET '15: Management of the Technology Age}

\section{CONCLUSION}

Initially, PESTLE is used to evaluate electric cars and gasoline cars from six influencing factors (political, environmental, social, technology, legal, and economic). From the environmental perspective, EVs may have advantages over gasoline cars. However, people argue that this is true if the electricity is green. If not, the process to generate electricity will produce greenhouse gases as well.

Four compact electric cars and five gasoline cars are selected to calculate the EUAC during ownership. By comparing respondent EUACs, it is possible to find the best economic car at the different return of federal tax credit for EVs.

The sensitivity analysis against the return of tax credits shows that the best economic car is the Chevrolet Spark EV if the full return of tax credit is received and the Toyota Corolla L 4Dr Sedan will be the winner if the return is less than $70 \%$ of the tax credit.

The sensitivity analysis against the gasoline shows that the preferred car will not be preferable anymore if the extent of the change is big enough. However, it is really hard to foresee the change of gasoline prices because they relate to many uncertain factors.

\section{LIMITATION AND FUTURE RESEARCH}

In order to reduce the calculation complexity, state incentives for EVs were not included in the analysis because state incentives [46] may be different or do not exist at all. In more detailed future studies, state incentives should be categorized and considered.

The state fees and insurance costs are also fixed in the paper. On the hand the variation of the state fee is not too big and on the other hand it is the same for both EV and gasoline cars. Thus, the results should not be impacted. The insurance cost is individually dependent, and it applies for both EV and gasoline cars.

The fuel cost is based upon the 15,000 miles each year. If the miles per year are lower than this number, the result may be impacted. In future research, conducting a sensitivity analysis against the change of the number of miles per year would be very suitable.

The gasoline prices relate to many uncertain factors such as weather, exchange rates and inflation, geopolitical risks, non-OPEC supply growth, OPEC production decisions, spare production capacity, inventories, global economic growth, and speculation, hedging, investment [59]. The projected gasoline prices are forecasted based upon the current and foreseen factors. The mentioned uncertainties may change the projected gasoline price and impact the result and therefore a further sensitivity analysis of gasoline should be executed.

\section{REFERENCES}

[1] M. Bellis, Inventors - Electric Cars (1890 - 1930). Inventors.about.com, 2010.

[2] U. Eberle and R. von Helmolt, Sustainable transportation based on EV concepts: a brief overview. Royal Society of Chemistry, 2010.

[3] Wikipedia, "Government incentives for plug-in electric vehicles." [Online]. http://en.wikipedia.org/wiki/Government_incentives_for_plugin_electric_vehicles. [Accessed: 01-Jan-2015].

[4] P. Valdes, GM unveils Chevy Volt - Looking to the future (1) CNNMoney.com. Money.cnn.com, 2008.

[5] L. Lu, X. Han, J. Li, J. Hua, and M. Ouyang, "A review on the key issues for lithium-ion battery management in electric vehicles," $J$. Power Sources, vol. 226, pp. 272-288, Mar. 2013.

[6] R. Adany, Switching algorithms for extending battery life in Electric Vehicles. .

[7] "Plug-In Electric Drive Vehicle Credit (IRC 30D)." [Online]. Available: http://www.irs.gov/Businesses/Plug-In-Electric-VehicleCredit-(IRC-30-and-IRC-30D). [Accessed: 23-Nov-2014].

[8] R. A. Burgelman and A. S. Grove, "Toward Electric Cars and Clean Coal: A Comparative Analysis of Strategies and Strategy-Making in the U.S. and China," 2010.

[9] R. D. Atkinson, "Understanding the U. S . National Innovation System," no. June, pp. 1-27, 2014.

[10] "The History of the Electric Car | Department of Energy." [Online] Available: http://www.energy.gov/articles/history-electric-car. [Accessed: 14-Dec-2014].

[11] “ATVM Loan Program | Department of Energy." [Online]. Available: http://www.energy.gov/lpo/services/atvm-loan-program. [Accessed: 14-Dec-2014].

[12] "Auto Industry." [Online]. Available: http:/www.treasury.gov/initiatives/financial-stability/TARPPrograms/automotive-programs/Pages/default.aspx. [Accessed: 31Dec-2014].

[13] A. Y. Debye, "E-car i ndustry analysis from the perspective of business model dynamics," University of Twente, Enschede, Netherlands, 2014.

[14] "What's in Store for Electric Vehicle Manufacturing? : Media Center." [Online]. Available: http://www.ibisworld.com/media/2013/06/13/whats-in-store-forelectric-vehicle-manufacturing/. [Accessed: 31-Dec-2014].

[15] "Electric cars suffer worst depreciation." [Online]. Available: http://www.telegraph.co.uk/motoring/greenmotoring/10478975/Electric-cars-suffer-worst-depreciation.html. [Accessed: 31-Dec-2014].

[16] "Shopping for Used Electric Cars." [Online]. Available: http://www.carfax.com/guides/car-research/hybrid-electric/electriccars. [Accessed: 31-Dec-2014].

[17] "Depreciation hits electric cars hard." [Online]. Available: http://www.usatoday.com/story/money/cars/2013/12/26/plug-in-carselectric-cars-depreciation-resale-residual-value/4194373/. [Accessed: 31-Dec-2014].

[18] "California Insurance Discounts: California Car, Home \& Life Insurance | Farmers." [Online]. Available: http://www.farmers.com/california/. [Accessed: 31-Dec-2014].

[19] "New Auto Insurance Discounts." [Online]. Available: https://www.electricinsurance.com/Products_Services/Auto/discounts/n ew_auto_discounts/index.asp. [Accessed: 31-Dec-2014].

[20] "STATE OF FLORIDA: Electric Vehicle Car Insurance Benefit," 2009. [Online]. Available: https:/www.nissanusa.com/ev/media/pdf/incentives/nissan-leafincentive-22.pdf. [Accessed: 31-Dec-2014].

[21] "Cheap Auto Insurance Quotes Online - Rackins." [Online]. Available: http://www.rackins.com/. [Accessed: 31-Dec-2014].

[22] "Alternative Fuels Data Center: Batteries for Hybrid and Plug-In Electric Vehicles." [Online]. Available: http://www.afdc.energy.gov/vehicles/electric_batteries.html. [Accessed: 31-Dec-2014].

[23] "Uncovering the post-vehicle value in lithium-ion batteries | E-waste and Batteries - United States - Recycling News | Recycling 
International - recycling magazine for professionals by professionals |." [Online]. Available: http://www.recyclinginternational.com/recyclingnews/8052/e-waste-and-batteries/united-states/uncovering-postvehicle-value-lithium-ion-batteries. [Accessed: 31-Dec-2014].

[24] "Oil Price: Latest Price \& Chart for Crude Oil - NASDAQ.com." [Online]. Available: http://www.nasdaq.com/markets/crudeoil.aspx?timeframe $=18 \mathrm{~m}$. [Accessed: $31-$ Dec-2014].

[25] “• U.S. Automotive Industry - Statistics \& Facts | Statista." [Online]. Available: http://www.statista.com/topics/1721/us-automotiveindustry/. [Accessed: 31-Dec-2014].

[26] "The Green-Washing Of Clean Energy Branding." [Online]. Available: http://www.forbes.com/sites/energysource/2013/04/12/the-greenwashing-of-clean-energy-branding/. [Accessed: 31-Dec-2014].

[27] "Alternative Fuels Data Center: Electricity Research and Development." [Online]. Available: http://www.afdc.energy.gov/fuels/electricity_production.html. [Accessed: 31-Dec-2014].

[28] "Alternative Fuels Data Center: Emissions from Hybrid and Plug-In Electric Vehicles." [Online]. Available: http://www.afdc.energy.gov/vehicles/electric_emissions.php. [Accessed: 31-Dec-2014].

[29] "The Cold Truth: Icy Temps Can Slash An Electric Car's Range By More Than Half." [Online]. Available: http://www.forbes.com/sites/jimgorzelany/2014/03/24/the-cold-truthicy-temps-can-slash-an-electric-cars-range-by-more-than-half/. [Accessed: 31-Dec-2014].

[30] "How Technology Could Reduce the Cold Weather Drain on EV Batteries | MIT Technology Review." [Online]. Available: http://www.technologyreview.com/news/522496/electric-vehicles-outin-the-cold/. [Accessed: 31-Dec-2014].

[31] "All-Electric Vehicles." [Online]. Available: http://www.fueleconomy.gov/feg/evtech.shtml. [Accessed: 31-Dec2014].

[32] "Are Electric Cars Safe in Accidents? - HowStuffWorks." [Online]. Available: http://auto.howstuffworks.com/are-electric-cars-safe-inaccidents.htm. [Accessed: 31-Dec-2014].

[33] "The Truth About Electric Car Safety - Green Transportation MOTHER EARTH NEWS." [Online]. Available: $\mathrm{http}: / / \mathrm{www} . m o t h e r e a r t h n e w s . c o m / g r e e n-t r a n s p o r t a t i o n / e l e c t r i c-c a r-$ safety-zkcz12zalt.aspx\#axzz3LSbaYeq7. [Accessed: 31-Dec-2014].

[34] "Is it easy to charge an electric car?" [Online]. Available: http://www.thechargingpoint.com/knowledge-hub/hot-topics/hottopics-charging.html. [Accessed: 31-Dec-2014].

[35] "Economies of Scale - benefits." [Online]. Available: http://www.referenceforbusiness.com/encyclopedia/EcoEnt/Economies-of-Scale.html. [Accessed: 31-Dec-2014].

[36] "Alternative Fuels Data Center: Developing Infrastructure to Charge Plug-In Electric Vehicles." [Online]. Available: http://www.afdc.energy.gov/fuels/electricity_infrastructure.html. [Accessed: 31-Dec-2014].

[37] "Alternative Fuels Data Center: Oregon Laws and Incentives for Electricity." [Online]. Available: http://www.afdc.energy.gov/fuels/laws/ELEC/OR. [Accessed: 31-Dec2014].

[38] J. Todd, J. Chen, and F. Clogston, "Creating the Clean Energy Economy: Analysis of the Ecectric Vehicle Industry."

[39] "Vehicle Technologies Office: Advanced Combustion Engines | Department of Energy." [Online]. Available: http://energy.gov/eere/vehicles/vehicle-technologies-office-advancedcombustion-engines. [Accessed: 31-Dec-2014].

[40] "Best Affordable Compact Cars Rankings | U.S. News Best Cars." [Online]. Available: http://usnews.rankingsandreviews.com/carstrucks/rankings/Affordable-Compact-Cars/. [Accessed: 23-Nov-2014].

[41] "Car Finder - Find A Car \& Browse New Cars | Edmunds.com." [Online]. Available: http://www.edmunds.com/finder/car-finder-
results.html\#!new/type:Electric/baseMsrp:asc/15. [Accessed: 23-Nov2014].

[42] "U.S. Consumers Hold on to New Vehicles Nearly Six Years, an AllTime High - Polk - Company - News." [Online]. Available: https://www.polk.com/company/news/u.s._consumers_hold_on_to_ne w_vehicles_nearly_six_years_an_all_time_high. [Accessed: 24-Nov2014].

[43] “• U.S. vehicles: length of ownership 2012 | Statistic." [Online]. Available: http://www.statista.com/statistics/276537/length-of-vehicleownership-in-the-united-states/. [Accessed: 24-Nov-2014].

[44] "Length of Ownership Returning to More Normal Levels; New Registrations Continue Slow Climb | Autoremarketing." [Online]. Available: http://www.autoremarketing.com/trends/length-ownershipreturning-more-normal-levels-new-registrations-continue-slow-climb. [Accessed: 24-Nov-2014].

[45] "Daily Treasury Yield Curve Rates." [Online]. Available: http://www.treasury.gov/resource-center/data-chart-center/interestrates/Pages/TextView.aspx?data=yield. [Accessed: 24-Nov-2014].

[46] "Incentives for Plug-in Hybrids and Electric Cars | PluginCars.com." [Online]. Available: http://www.plugincars.com/federal-and-localincentives-plug-hybrids-and-electric-cars.html. [Accessed: 23-Nov2014].

[47] W. G. Sullivan, E. M. Wicks, and C. P. Koelling, Engineering Economy, 15th ed. Upper Saddle River: Perason Education, 2011.

[48] "New 2014 Chevrolet Spark EV 2LT 4Dr Hatchback Research IntelliChoice.com.” [Online]. Available: http://www.intellichoice.com/1-12-2014-55490-0/2014-chevroletspark-ev-2lt-4dr-hatchback.html. [Accessed: 23-Nov-2014].

[49] "New 2014 Honda Fit EV 4Dr Hatchback Cost Of Ownership \& Depreciation - IntelliChoice.com." [Online]. Available: http://www.intellichoice.com/1-12-2014-58882-1/2014-honda-fit-ev4dr-hatchback-cost-of-ownership.html. [Accessed: 23-Nov-2014].

[50] "New 2014 Ford Focus BEV 4Dr Hatchback Research IntelliChoice.com." [Online]. Available: http://www.intellichoice.com/1-12-2014-53700-0/2014-ford-focus-bev4dr-hatchback.html. [Accessed: 23-Nov-2014].

[51] "New 2014 Nissan LEAF S 4Dr Hatchback Research IntelliChoice.com." [Online]. Available: http://www.intellichoice.com/1-12-2014-54494-0/2014-nissan-leaf-s4dr-hatchback.html. [Accessed: 23-Nov-2014].

[52] "New 2014 Kia Soul 4Dr Wagon (Auto) Research IntelliChoice.com." [Online]. Available: http://www.intellichoice.com/1-12-2014-54201-0/2014-kia-soul-4drwagon-automatic.html. [Accessed: 24-Nov-2014].

[53] "New 2014 Honda Civic LX 4Dr Sedan (Auto) Research IntelliChoice.com." [Online]. Available: http://www.intellichoice.com/1-12-2014-53952-0/2014-honda-civic-lx4dr-sedan-automatic.html. [Accessed: 24-Nov-2014].

[54] "New 2014 Mazda Mazda3 i SV 4Dr Sedan (Auto) Research IntelliChoice.com." [Online]. Available: http://www.intellichoice.com/1-12-2014-54293-0/2014-mazdamazda3-i-sv-4dr-sedan-automatic.html. [Accessed: 24-Nov-2014].

[55] "New 2014 Toyota Corolla L 4Dr Sedan (Auto) Research IntelliChoice.com." [Online]. Available: http://www.intellichoice.com/1-12-2014-54881-0/2014-toyota-corolla1-4dr-sedan-automatic.html. [Accessed: 24-Nov-2014].

[56] "New 2014 Ford Focus S 4Dr Sedan Research - IntelliChoice.com." [Online]. Available: http://www.intellichoice.com/1-12-2014-537010/2014-ford-focus-s-4dr-sedan.html. [Accessed: 24-Nov-2014].

[57] "Car Depreciation Calculator: Eye-Opening Opportunity Cost Feature." [Online]. Available: http://www.free-online-calculator-use.com/cardepreciation-calculator.html. [Accessed: 24-Nov-2014].

[58] "Car Depreciation Calculator." [Online]. Available: http://www.money-zine.com/calculators/auto-loan-calculators/cardepreciation-calculator/. [Accessed: 24-Nov-2014].

[59] N. G. Industry, “Gasoline Prices ?,” no. November, 2014. 